\title{
Identification and analysis of the germin-like gene family in soybean
}

\author{
Mo Lu', Ying-Peng Han ${ }^{1}$, Ji-Guo Gao ${ }^{2}$, Xiang-Jing Wang ${ }^{2 *}$, Wen-Bin Li $i^{*}$
}

\author{
Abstract \\ In line 12 of page 1, replace "GmGER 9" with "GmGER 15".
}

\section{Correction}

After the publication of this work [1], we became aware of the fact that the gene name 'GmGER 9' was mistakenly used throughout the gene function analyses in the original manuscript due to an error between the gene identification number recorded in our notebook and the nearest matching GenBank accession. The gene name 'GmGER 9' should be changed to 'GmGER 15' in the following places:

\section{Results}

In the last Paragraph of the results section (page 9), replace "GmGER 9" with "GmGER 15".

\section{Discussion}

In line 2 of page 12, replace "GmGER 9" with "GmGER 15 ".

In line 5 of page 12 , replace "GmGER 9" with "GmGER 15".

In line 8 of page 12, replace "GmGER 9" with "GmGER 15".

\section{Methods}

In line 1 of the Paragraph "Salt tolerance assay" on page 13, replace "GmGER 9"

with "GmGER 15".

\footnotetext{
* Correspondence: wangxiangjing2008@yahoo.com.cn; wenbinli@neau.edu. cn

'Soybean Research Institute (Key Laboratory of Soybean Biology in Chinese Ministry of Education), Northeast Agricultural University, Harbin, 150030, PR China

${ }^{2}$ Department of Life Science, Northeast Agricultural University, Harbin,

150030, PR China

Full list of author information is available at the end of the article
}

\section{Author details}

${ }^{1}$ Soybean Research Institute (Key Laboratory of Soybean Biology in Chinese Ministry of Education), Northeast Agricultural University, Harbin, 150030, PR China. ${ }^{2}$ Department of Life Science, Northeast Agricultural University, Harbin, 150030, PR China.

Received: 7 January 2011 Accepted: 10 January 2011

Published: 10 January 2011

\section{Reference}

1. Lu M, Han YP, Gao JG, Wang XJ, Li WB: Identification and analysis of the germin-like gene family in soybean. BMC Genomics 2010, 11:620.

doi:10.1186/1471-2164-12-16

Cite this article as: Lu et al:: Identification and analysis of the germin-like gene family in soybean. BMC Genomics 2011 12:16.

\section{Biomed Central}

Submit your next manuscript to BioMed Central and take full advantage of:

- Convenient online submission

- Thorough peer review

- No space constraints or color figure charges

- Immediate publication on acceptance

- Inclusion in PubMed, CAS, Scopus and Google Scholar

- Research which is freely available for redistribution 